\title{
Knowledge, attitude towards human papillomavirus and HPV vaccine among medical students of a tertiary care teaching hospital in India
}

\author{
Saswati Tripathy ${ }^{1}$, Satyajit Mohapatra ${ }^{2}$, M. Muthulakshmi ${ }^{1}$, R. Jamuna Rani $^{2}$
}

\begin{abstract}
${ }^{1}$ Department of Obstetrics \& Gynaecology, SRM Medical College Hospital \& Research Centre, Chennai, India
${ }^{2}$ Department of Pharmacology, SRM Medical College Hospital \& Research Centre, Chennai, India
\end{abstract}

Received: 05 September 2015

Accepted: 07 October 2015

\author{
*Correspondence: \\ Dr. Saswati Tripathy, \\ E-mail: saswtitripathy@yahoo.com
}

Copyright: $\odot$ the author(s), publisher and licensee Medip Academy. This is an open-access article distributed under the terms of the Creative Commons Attribution Non-Commercial License, which permits unrestricted non-commercial use, distribution, and reproduction in any medium, provided the original work is properly cited.

\begin{abstract}
Background: The objective of the study was to assess the awareness of the human papillomavirus (HPV) infections and vaccination among the young students of a tertiary care teaching hospital.

Methods: A cross sectional study was done among the students of a tertiary care teaching hospital. The students were assured of the confidentiality and were provided a questionnaire about HPV infection and HPV vaccine.

Results: About $94.3 \%$ of students implicated that HPV is a causative agent of cervical cancer and 5.7\% students didn't know about the association. About $72.1 \%$ were aware of the availability of the vaccine to be immunized against HPV infection but $3.3 \%$ answered wrongly and $24.6 \%$ didn't know about it. Thirty one percent students knew the correct age of initiation of the vaccination, $23 \%$ answered wrongly and about $45.9 \%$ of the students didn't know the answer. Only $4.1 \%$ of the students have been vaccinated with HPV vaccine. About $63.9 \%$ students didn't agree to vaccinate themselves against HPV as they felt it would give a false sense of security and $68.8 \%$ of the students were against the routine vaccination of the young Indian population against HPV as the sexual exposure occurs at late age. $73 \%$ students referred the age of vaccination to be $>25$ years.

Conclusions: Lack of knowledge among medical students can be detrimental to the health of the society. So there is a need to create awareness among the future health educators against various aspects of HPV, cervical cancers and its prevention.
\end{abstract}

Keywords: Human papillomavirus, Knowledge, Attitude, HPV vaccine

\section{INTRODUCTION}

Human papillomavirus (HPV) is one of the most common causes of sexually transmitted infections. Cervical cancer is ranked as the second most common cancer among women worldwide and is a major cause of female mortality. Approximately 5,00,000 new cases of cervical cancer and 2,60,000 cancers related deaths occur annually. ${ }^{1}$ The incidence of cervical cancer is increasing in Latin America and Caribbean, sub Saharan Africa and South- East Asia. ${ }^{1}$ In India, cervical cancer remains as the commonest female cancer and the annual incidence of more than $1,32,000$ every year. ${ }^{2}$ Recognition of this dreaded virus in cervical cancer has led to stimulated search for preventive vaccines. HPV vaccines have been introduced in many developed countries in recent years. But with an aim to achieve significant reduction in worldwide cancer, these have been introduced in many developing countries too.

Two types of HPV vaccines have been developed and clinically evaluated for prophylactic vaccination. Gardasil (Merck and Co., USA) and Cervarix (GlaxoSmithKline, Belgium) have been approved in several countries like USA, Australia and in the European Union. These have been licensed in India for use in females (primary vaccination at 10-12 years, catch-up up to 26 years). As there is a rapid urbanization in countries like India, the knowledge about this viral infection and the prevention 
measures should be known to all the target population. It is important to understand the obstacles to vaccination arising from the attitude from the young people. An educational initiative targeting health care professionals has a great value. Because in future, these professionals will be the first line information resources and will be having a major role in spreading awareness among a wide range of population. So we conducted this study to assess the knowledge and attitude of the young health professional students who are the best persons to disseminate the information of HPV and HPV vaccinations.

\section{METHODS}

A cross sectional questionnaire based study was conducted after approval of the Institutional Ethics Committee. The medical students of first year to third year both genders during the study period (March 2013April 2013) were included in the study. The only exclusion criterion was unwillingness of the student to participate in the study. The personal information and confidentiality of the student was guaranteed. A questionnaire having fifteen questions was designed to acquire information about knowledge and understanding of the disease, concept of vaccination, the level of acceptance and attitude towards vaccination. The validity of the questionnaire was done in a pilot study among the interns and post graduates. After analysing the validity, the participants were asked to answer the questionnaire. They were asked to fill the questionnaire and return back in the same session. As cervical cancer is a major health problem among females, the knowledge, awareness and acceptance of the female students was compared with the male students. The data obtained were analysed with descriptive statistics, frequencies and percentages were calculated for each item in the questionnaire.

\section{RESULTS}

A total of 150 medical students of aged between 18-25 years were surveyed for this study. Out of 150 students, only 122 students responded and submitted the completed questionnaire. Twenty eight questionnaires were incomplete and were excluded from the analysis. The mean age of these students was $19.04 \pm 1.01$ years. Seventy seven $(63.1 \%)$ were female and forty five $(36.9 \%)$ were male students. All the students were unmarried. One hundred eleven $(90.9 \%)$ students were aware of the availability of the HPV vaccine and $9 \%$ of the students didn't hear about the vaccine at all. Most of them have heard about the vaccine through word of mouth $(58.6 \%)$, internet $(13.5 \%)$, newspaper (9.9\%), magazine $(9 \%)$, others like TV ads, posters $(9 \%)$.

\section{Knowledge of HPV infection}

The answers were analysed for the awareness of the students regarding the Human papillomavirus and its infection. One hundred and fifteen students (94.3\%) implicated that HPV is a causative agent of cervical cancer. But only seven (5.7\%) students didn't know about the association. According to $75 \%$ of students, HPV infection spreads by sexual and non-sexual route. Only $25 \%$ of students replied that HPV spreads by only sexual route. Eighty two percent students answered that HPV can cause genital warts and other precancerous lesions; whereas eighteen percent didn't know about it. None of the students answered correctly regarding the time of progression of HPV infection to cervical cancer.

Table 1: Knowledge about HPV vaccination.

\begin{tabular}{|llll|}
\hline $\begin{array}{l}\text { Questions } \\
\text { parameters }\end{array}$ & $\begin{array}{l}\text { Right } \\
\text { answers } \\
(\%)\end{array}$ & $\begin{array}{l}\text { Wrong } \\
\text { answer } \\
(\%)\end{array}$ & $\begin{array}{l}\text { Did not } \\
\text { know } \\
(\%)\end{array}$ \\
\hline $\begin{array}{l}\text { Schedule of } \\
\text { vaccination }\end{array}$ & 23 & 8.2 & 68.9 \\
\hline $\begin{array}{l}\text { Route of } \\
\text { administration }\end{array}$ & 59.8 & 5.7 & 34.4 \\
\hline $\begin{array}{l}\text { Commercially } \\
\text { available } \\
\text { vaccines }\end{array}$ & 12.3 & 6.6 & 81.1 \\
\hline $\begin{array}{l}\text { Efficacy of } \\
\text { the vaccines }\end{array}$ & 23 & 7.1 & 69.9 \\
\hline $\begin{array}{l}\text { Follow up } \\
\text { anal/cervical } \\
\text { screening }\end{array}$ & 45.9 & 6.6 & 47.5 \\
\hline
\end{tabular}

Table 2: Attitude of the medical students for HPV vaccination.

\begin{tabular}{|lll|}
\hline $\begin{array}{l}\text { Parameters measured } \\
\text { in the questionnaire }\end{array}$ & \\
\hline $\begin{array}{l}\text { Have you vaccinated } \\
\text { with HPV before }\end{array}$ & Yes $(4.1 \%)$ & No (95.9\%) \\
\hline $\begin{array}{l}\text { Will you give consent } \\
\text { for vaccination against }\end{array}$ & Yes $(36.1 \%)$ & No $(63.9 \%)$ \\
HPV & & \\
\hline $\begin{array}{l}\text { HPV vaccine should be } \\
\text { prescribed routinely to }\end{array}$ & Yes $(31.1 \%)$ & No $(68.9 \%)$ \\
$\begin{array}{l}\text { young population in } \\
\text { India }\end{array}$ & & \\
\hline $\begin{array}{l}\text { Age of the vaccination } \\
15-25 \text { yrs. }\end{array}$ & $12.3 \%$ & - \\
$>25$ yrs. & $73 \%$ & - \\
$>35$ yrs. & $14.8 \%$ & - \\
\hline $\begin{array}{l}\text { Cost of the HPV } \\
\text { vaccine }\end{array}$ & & \\
$\begin{array}{l}\text { Rs } 500 \\
\text { Rs } 1000\end{array}$ & $21.3 \%$ & - \\
Rs 2000 & $68.9 \%$ & - \\
\hline
\end{tabular}

\section{Knowledge of HPV vaccination}

Eighty eight students $(72.1 \%)$ were aware that there is vaccination available to be immunized against HPV infection. But four students (3.3\%) answered wrongly 
and thirty students (24.6\%) didn't know about the availability of the vaccine. Only $6.6 \%$ of the students answered that HPV vaccine prevents against all type of viruses that cause cervical cancer. But majority of the students $(54.9 \%)$ didn't know about the prevention. About $9.8 \%$ of the students answered that vaccine could protect against other sexually transmitted diseases. Regarding the availability of the vaccine for both boys and girls, about $41.8 \%$ of the students answered correctly, $29.5 \%$ answered wrongly and $28.7 \%$ did not know the answer. Thirty one percent students knew the correct age of initiation of the vaccination, $23 \%$ answered wrongly and about $45.9 \%$ of the students didn't know the answer. The response to different parameters in the questionnaire that were asked to the students to assess their knowledge about HPV vaccine is mentioned in Table 1.

\section{Attitude of the students towards HPV vaccination}

The questionnaire was designed to assess the attitude of our students towards the HPV vaccination. About $4.1 \%$ of the students have been vaccinated against HPV and 95.9\% were not vaccinated prior to this study. But only $36.1 \%$ of students were ready to give consent for vaccination as compared to $63.9 \%$ of students who were not willing for vaccination. Majority of students (68.9\%) said that there is no need of routine vaccination of young Indian population as the sexual exposure occurs at late stage of the life and the age of vaccination should be $>25$ year as answered by $73 \%$ students. But $31.1 \%$ students felt that there is a need for routine vaccination to young population due to rapid urbanization and changes in culture. Regarding the cost of the vaccine, $68.9 \%$ felt that the cost of the vaccine should be one thousand rupees for affordable to most of the people (Table 2).

\section{DISCUSSION}

Cancer is an invincible disease which has plagued mankind for centuries. There are different modalities of treatment of cancers. Recently, a lot of researches are going on for vaccine which can prevent cancers. The morbidity and mortality associated with genital HPV induced lesion and poor immunity conferred by natural infection have led to search for prophylactic vaccine. The development of HPV vaccine has shown an advancement of fight against cervical cancers. At present two prophylactic HPV vaccines are available internationally. The enthusiasm of the Indian pharmaceutical companies for development and marketing of HPV vaccine has led this virus into spotlight. But the awareness of the association of Human papillomavirus with cervical cancer and its prevention by HPV vaccine is very low among the young Indian population. A study conducted by Saha et al in India revealed a very low level of awareness among the graduate and postgraduate students. ${ }^{3}$ Another study conducted to find out awareness about the risk factors for cervical cancer among the educated youth in India, Sri Lanka and Nepal and the average awareness in this regard was found to be $66 \%$ in
India, $58.8 \%$ in Nepal and $57.7 \%$ in Srilanka. ${ }^{4}$ This study was conducted to look for the awareness and attitude of the medical students in our region. Most of our students knew the association of the HPV with cervical cancer and the route of transmission of this virus. Majority of the students were aware of the availability of the HPV vaccine through sources like word of mouth, internet, magazine etc. This was similar to the findings of study done by Pandey et al. ${ }^{5}$ Another study has observed a very low level of awareness about HPV and HPV vaccine among their students. ${ }^{6}$ The study by Durusoy et al., on HPV vaccine awareness and willingness of the first year students have revealed that the knowledge amongst them was poor and only $11.6 \%$ females intended to be vaccinated. ${ }^{7}$ In our study only $36.1 \%$ students gave willingness for HPV vaccination as compared to $88 \%$ in the study done by Mehta S, et al. ${ }^{6}$ A study done by Naki et al on the awareness, knowledge and attitudes related to HPV infection and vaccine among non-obstetriciangynecologist healthcare providers suggested that HPV related knowledge in the physicians was significantly higher and were more willing to get vaccinated as compared to non-physician staffs. ${ }^{8}$ The study by Gimet GD et al has shown that $48 \%$ of the non-vaccinated population were unlikely to go for vaccination and the reasons cited were that they were married and in monogamous relationship, vaccines are new with inappropriate information. ${ }^{9}$ Similarly in our study, most of the students were not willing to give consent for vaccination and cited the reason that the vaccine gives a false sense of security. They even answered that the vaccination should be given at the age more than 25 years as the sexual exposure occurs late in India.

The awareness and knowledge about HPV infection and vaccine in medical students in our study was high because of the cohort represented the students from first year to third years who were exposed to the subject only but not much of clinical exposure. But the attitude among the students regarding HPV vaccination was low. The misconception in the general public would be even more and acceptance also would be very poor. This could have detrimental to the health of the society as the medical students are the future health care providers, health educators. So there is a need for an aggressive health education programme, seminars, group discussions, and interactive sessions among the students regarding the HPV where all doubts regarding HPV and its association with cervical cancer, its prevention can be clarified. Even the pharmaceutical companies who are marketing the HPV vaccine and those who involved in the development of the HPV vaccine can take initiative to conduct educational programme regarding awareness of HPV infections. Even the government is planning the strategy to include this vaccine in the routine immunization schedule, but before that proper information should reach to the people.

The limitation of our study was that the study population was from one medical college and from 1st year to 3rd 
year students which does not represent the knowledge of all medical students. Inclusion of other students from different courses like dental, nursing, physiotherapy etc. will increases the impact of this study in future.

\section{CONCLUSIONS}

The present study is an initiative to find out the level of awareness about one of the currently most discussed topic of cervical cancer vaccine, among the future healthcare providers. The existing gap between the knowledge and attitude of the students can be overcome by various educational programmes. In fact, all health workers need to be educated about how to help patients to understand the advantages and limitations of this cervical cancer prevention strategy.

Funding: No funding sources Conflict of interest: None declared

Ethical approval: The study was approved by the Institutional Ethics Committee

\section{REFERENCES}

1. Human Papilloma Virus vaccines. WHO position paper. Wklyepidemicol Rec. 2009;84:118-31.

2. Parkin DM, Bray F, Ferlay J, Pisani P, Global Cancer statistics,2002. CA Cancer J Clin. 2005;55:74-108.

3. Saha A, Nag Chaudhury A, Bhowmik P, Chatterjee R. Awareness of Cervical Cancer Among Female Students of Premier Colleges in Kolkata, India. Asian Pacific Journal of Cancer Prevention. 2010;11:1085-90.
4. Teresa J, Brijesh S, Chacchu B, Jenny C. Awareness of Cervix Cancer Risk Factors in Educated Youth: A Cross-Sectional, Questionnaire Based Survey in India, Nepal, and Sri Lanka. Asian Pacific J Cancer Prev. 2011;12:1707-12.

5. Pandey D, Vanya V, Bhagat S, VS B, Shetty J. Awareness and Attitude towards Human Papillomavirus (HPV) Vaccine among Medical Students in a Premier Medical School in India. PLoS ONE. 2012;7(7):e40619.

6. Mehta S, Rajaram S, Goel G, Goel N. Awareness about Human papilloma virus and its vaccine among medical students. Indian $\mathrm{J}$ community medicine. 2013;38:92-4.

7. Durusoy R, Yamazhan M, Tasbakan MI, Ergin I, Aysin M, Pullukcu H, et al. HPV vaccine awareness and willingness of first year students entering university in western Turkey. Asian Pac J Cancer Prev. 2010;11:1695-701.

8. Naki MM, Celik H, Api O, Celik H, Kars B, Yasar E et al. Awareness, Knowledge and attitude related to HPV infection and vaccine among non-obstetriciangynaecologist healthcare providers. J TurkishGerman Gynecol Assoc. 2010;11:16-21.

9. Zimet GD, Weiss TW, Rosenthal SL, Good MB, Vichinin MD. Reasons for non-vaccination against HPV and future vaccination intentions among 19-26 year old women. BMC womens Health. 2010;10:27.

Cite this article as: Tripathy $\mathrm{S}$, Mohapatra $\mathrm{S}$, Muthulakshmi M, Jamuna Rani R. Knowledge, attitude towards human papillomavirus and HPV vaccine among medical students of a tertiary care teaching hospital in India. Int J Reprod Contracept Obstet Gynecol 2015;4:1771-4. 